\title{
Isolation of $E$. coli from Bovine Mastitis and their Antibiotic Sensitivity Pattern
}

\author{
A. Singh, D. Chhabra ${ }^{*}$, R. Sikrodia, S. Shukla, R. Sharda and S. Audarya \\ Department of Veterinary Microbiology, College of Veterinary Science and Animal \\ Husbandry, Mhow (M.P.), India \\ *Corresponding author
}

\section{A B S T R A C T}

\section{Keywords}

AST, Antibiotics, Mastitis, Buffaloes

Article Info

Accepted:

04 September 2018

Available Online:

10 October 2018
A total of 300 milk samples from buffaloes were evaluated for mastitis and incidence of $E$. coli. Overall, 157 milk samples $(52.33 \%)$ were positive for mastitis and out of these positive isolates, 27 bacterial isolates $(17.19 \%)$ were identified as E. coli. All the 27 isolates of $E$. coli were tested for in vitro sensitivity towards 15 antibacterial drugs. The highest resistance was attributed towards antibiotic Kanamycin followed by Cefotaxime, Trimethoprim, Cefotaxime + Clavulanic acid, Amoxycillin, Cefixime, Tetracycline, Ampicillin + Salbactum, Amikacin, Chloramphenicol, Nitrofurantoin, Gentamicin, Cefoperazone, Ceftriaxone and Ciprofloxacin. Simultaneously resistance to 2 to 9 antibacterial agents, was observed in all 27 (100\%) isolates.

\section{Introduction}

Mastitis is considered to be the most common cause of injudicious antibiotic use in dairy animals which leads to treatment failure, escalated treatment costs and development of resistance to antimicrobials.

Inappropriate usage of antimicrobials such as wrong dose, drug or duration may contribute to the increase in antimicrobial resistance without improving the outcome of treatment (Williams, 2000).

Mastitis is defined as an inflammatory reaction of the parenchyma of the mammary gland that can be of an infectious, traumatic or toxic nature. It is mainly caused by microorganisms usually gram-negative and gram-positive bacteria, mycoplasmas, yeasts and algae (Zadoks et al., 2011). The multiplicity of the cause and emergence of resistance due to indiscriminate and prolonged use of antibiotics in absence of antibiogram is a major hurdle in the control of mastitis (Jeykumar et al., 2013).

The usage of antibiotics correlates with the emergence and maintenance of antibiotic resistant traits within pathogenic strains. These traits are coded by particular genes that may be carried on the bacterial chromosome, plasmids, transposones or on gene cassettes that are incorporated into integrons (Daka et al., 2012) thus are easily transferred among isolates. 


\section{Materials and Methods}

A total of 300 milk samples were collected from buffaloes and animals found positive for clinical and subclinical mastitis (SCM) were included in the present study. The cases of clinical mastitis were diagnosed on the basis of physical examination of udder (swelling, redness, pain on palpation, induration) and milk color- (yellow or blood tinged and consistency- watery, flakes, etc.). The subclinical mastitis was diagnosed by California mastitis test (Schalm et al., 1971).

\section{Isolation of bacteria}

Milk samples from clinical cases and those showing $(++/+++)$ or more reaction in CMT were cultured bacteriologically to isolate and identify the E. coli bacteria. Positive sample was inoculated in BHI and incubated aerobically at $37{ }^{\circ} \mathrm{C}$ for $24 \mathrm{hrs}$ and then streaked on nutrient agar media and incubated aerobically at $37^{\circ} \mathrm{C} 24 \mathrm{hrs}$ to obtain isolated single bacterial colonies.

The differential media and selective media used were MacConkey media and EMB, respectively. The gross cultural characteristics of the colonies were observed and after that Gram staining of cultures was done.

\section{Identification of bacteria}

The presumptive identification of bacterial isolates as E. coli was accomplished by colonial and bacterial morphology. Further, the biochemical tests were carried out as per procedure described by Cruickshank et al., (1973), Barrow and Feltham (1993), Collee et al., (1996) and Malik (2003).

Both traditional methods and readymade kits (Hi E. coli identification kits, Hi media) were used for biochemical characterization of $E$. coli isolates.

\section{Antibiotic sensitivity test}

In vitro antibiotic sensitivity test of the $E$. coli isolates towards 15 antibacterial drugs was conducted as per the method of Bauer et al., (1966). Antibiotics used in the present study were: Amikacin, Amoxicillin, Ampicillin, Cefixime, Cefoperazone, Ceftriaxone, Cefotaxime/clavulanic acid, Cefotaxime, Chloramphenicol, Ciprofloxacin, Gentamicin, Kanamycin, Nitrofurantoin, Tetracycline and Trimethoprim.

A loopful of the growth from slant was inoculated in BHI and incubated at $37{ }^{\circ} \mathrm{C}$ for 18-24 hrs. and then the surface of preincubated and sterile Muller Hinton agar (Hi Media) was uniformly smeared with the culture swab and the plate was kept at room temperature for $30 \mathrm{~min}$ to allow the inoculums to be adsorbed on the surface and then the antibiotic discs (Hi Media) were placed on the media surface at equal distances and sufficiently separated from each other. The plates were incubated overnight at $37{ }^{\circ} \mathrm{C}$. Diameters of clear zone of inhibition around antibiotic discs were measured in $\mathrm{mm}$. The interpretation of result was made in accordance with the instruction supplied by manufacture.

\section{Results and Discussion}

Antimicrobial agents are of great value for devising curative measures against bacterial infections. But antibiotic-resistant bacteria pose a severe challenge to both veterinary and health professions and dairy animal producers because they have a negative impact on therapy. Development of resistance has been attributed to the extensive therapeutic use of antimicrobials (Abo-Shama, 2014).

E. coli is the major pathogen causing environmental mastitis and it is one of the most important coliforms that have received 
more attention due to its high incidence relatively to other mastitis pathogens (ElSayed Lamey, 2013).

A total of 300 milk samples from buffaloes were evaluated for mastitis and incidence of $E$. coli. Overall, 157 milk samples (52.33\%) were positive for mastitis. Buffaloes have some characteristics that may contribute to greater risk of mastitis. For example, the udder is more pendulous in comparison with cattle (Moroni et al., 2006). The overall prevalence recorded in the present study was different from the reports of Farooq et al., 2008 who reported only $9.3 \%$ prevalence and Bhanot et al., 2012 who reported high (78.1\%) prevalence of buffalo mastitis.

Out of 157 buffalo mastitis positive isolates, 27 bacterial isolates $(17.19 \%)$ were identified as $E$. coli. The frequency of E. coli observed in present study was in close agreement with the data obtained by Khan and Muhammad (2005), Farooq et al., (2008), Hameed et al.,
(2008), Ali et al., (2011), Bhanot et al., (2012), El-Sayed Lamey et al., (2013) who observed 18\%, 16\%, 15.38\%, 16.18\%, 16.3\%, $18.47 \%$ frequency of $E$. coli, respectively in buffalo milk samples.

Antimicrobials are routinely used for treatment of dairy animals affected with clinical and subclinical infections. Over the years, antimicrobial susceptibility testing has become under scrutiny because of concerns about antimicrobial resistance, changes in methodology and the relationship between in vitro results and on-farm clinical outcomes (Idriss et al., 2014).

All the $27 E$. coli isolates were tested for in vitro sensitivity towards 15 antimicrobial drugs and interpreted according to the manufacturer's (HiMedia) instructions (Plate 1). These 15 antibiotics belonged to the seven groups viz. fluoroquinolones, aminoglycosides, tetracycline, cephalosporins, penicillin, beta lactum and sulphonamide.

Fig.1 Frequency of sensitivity to different antimicrobial agents

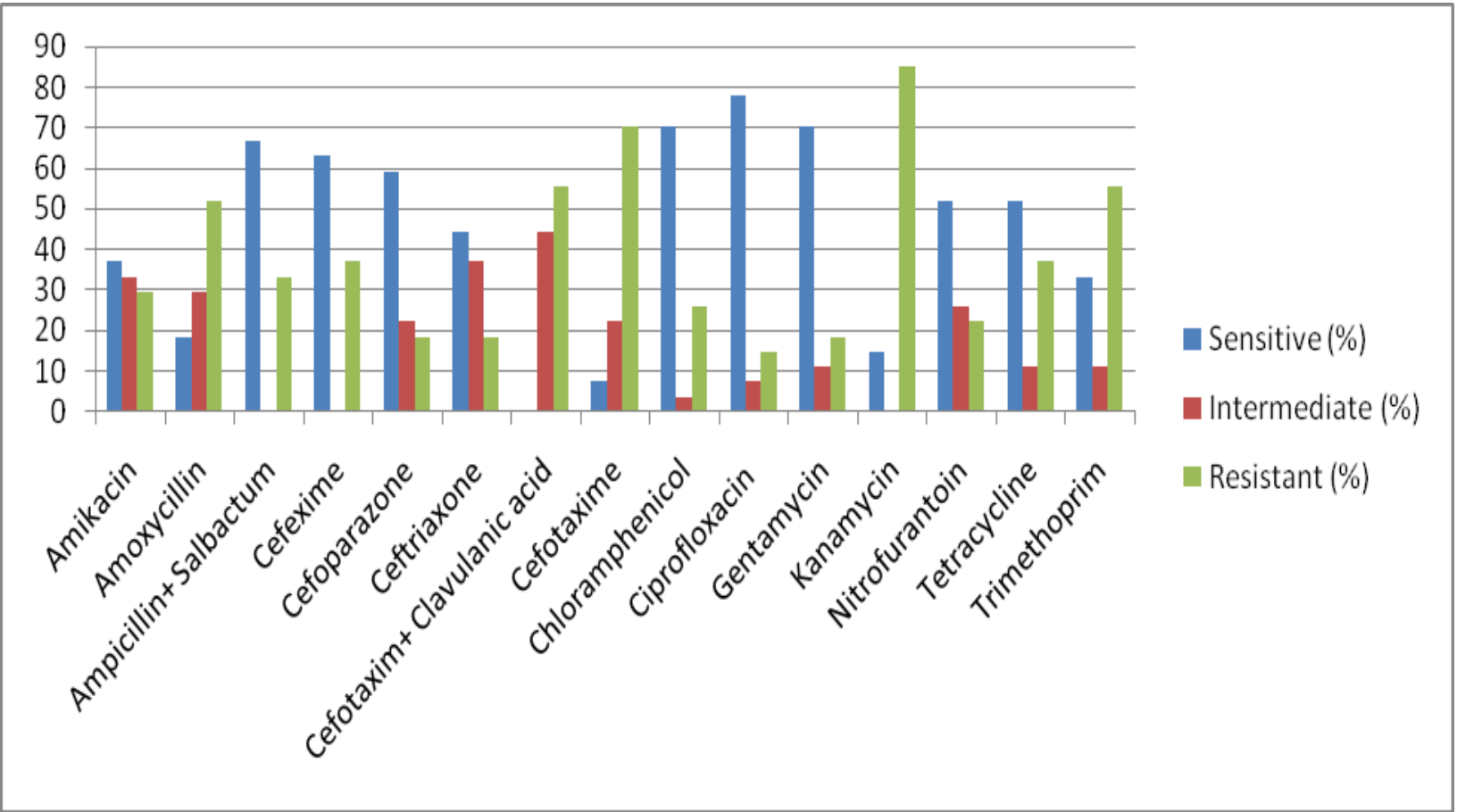


Fig.2 Multiple drug resistance in E. coli isolates

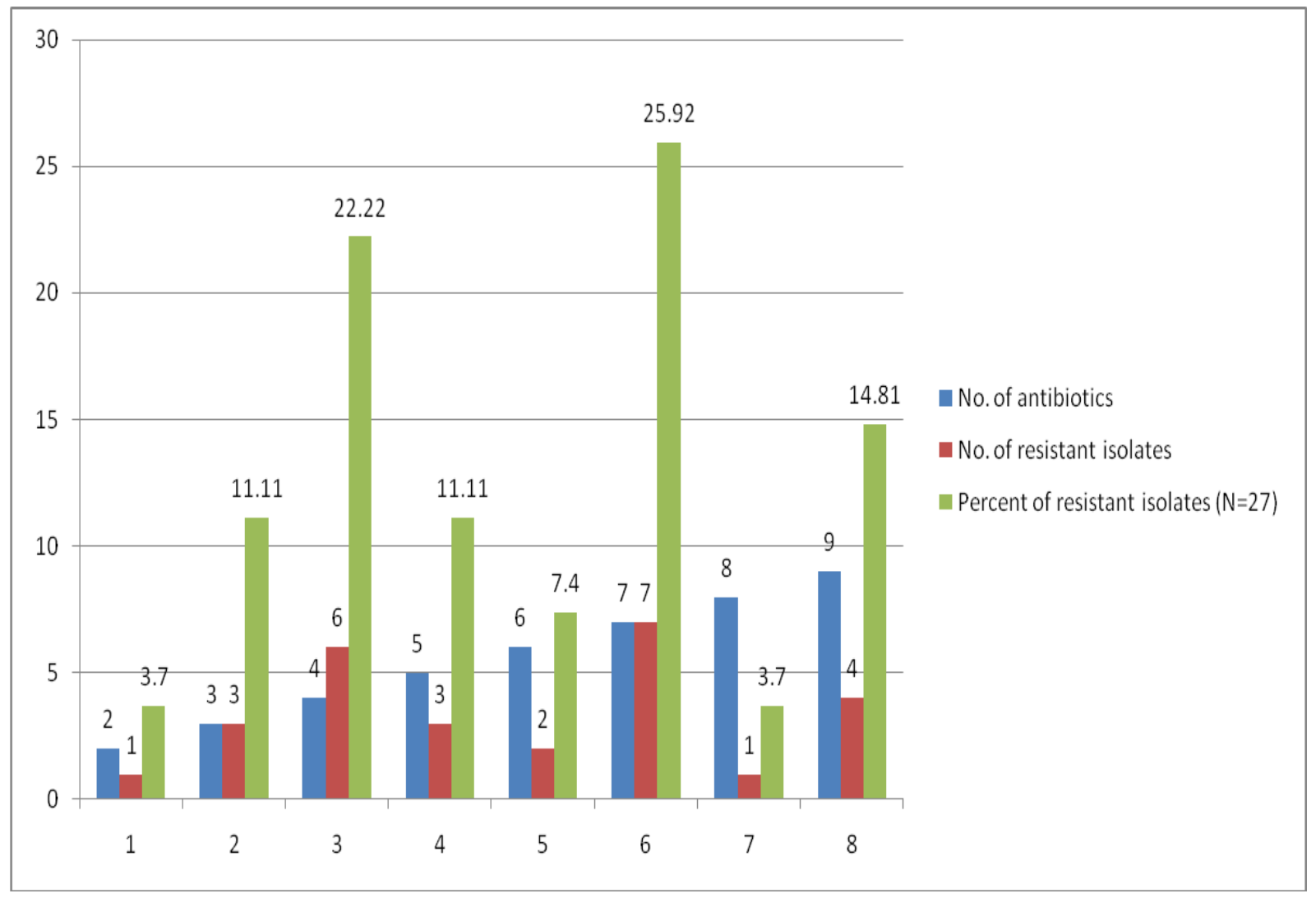

Plate.1 Results of antibiotic sensitivity test

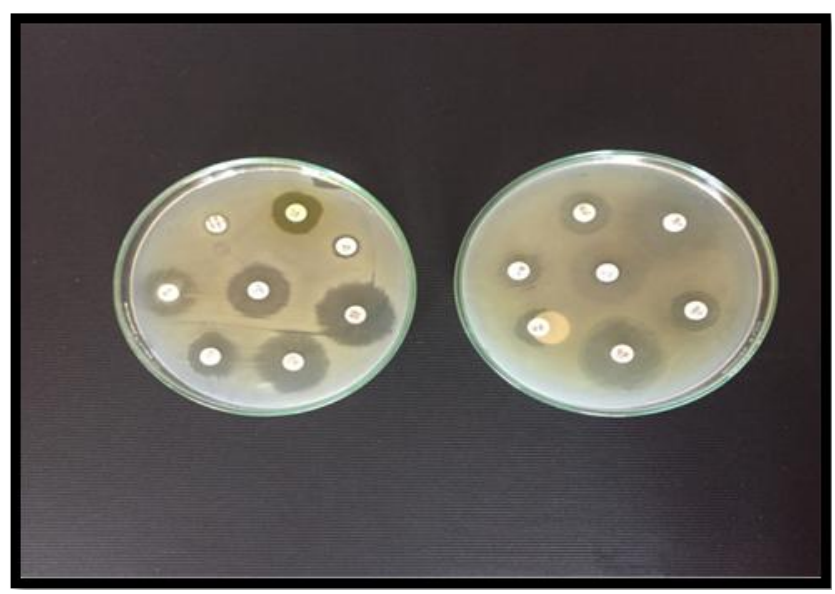

The highest resistance was attributed towards antibiotic Kanamycin (85.18\%) followed by Cefotaxime (70.37\%), Trimethoprim (55.55\%), Cefotaxime/clavulanic acid (55.55\%), Amoxycillin (51.85\%), Cefixime $(37.03 \%)$, Tetracycline $(37.03 \%)$, Ampicillin
+ salbactum (33.33\%), Amikacin (29.62\%), Chloramphenicol (25.92\%), Nitrofurantoin (22.22\%), Gentamicin, Cefoperazone and Ceftriaxone (18.51\%) and Ciprofloxacin $(14.81 \%)$. The highest sensitivity of E. coli was towards Ciprofloxacin antibiotic (Figure 
1). The E. coli isolates simultaneously resistant to 2 to 9 antibacterial agents, was observed in $27(100 \%)$ out of total 27 isolates. The maximum number of isolates was resistant to 7 drugs (Figure 2). Multidrug resistance in $E$. coli from milk sample was also reported by Zdolec et al., (2016). The level of resistance of organism to a particular drug might be due to the indiscriminate use of the respective drugs. Hence, antibiotic should be used at recommended dosage for appropriate time course preferably after performing the in vitro sensitivity testing.

Various antibiotics used for Antibiotic sensitivity test (AST) in this study has also been reported by other workers viz. Preethirani et al., (2015), Farooq et al., (2008), Ranjan et al., (2011), Kisku and Samad (2013) and Verma et al., (2018). There has been evidence of increase in resistance to wide range of drugs in $E$. coli from animals in India and abroad (Dhakal et al., 2007, Sumathi et al., 2008, Kalmus et al., 2011 and Jeykumar et al., 2013)

Khan et al., (2004) reported that E. coli isolates were $100 \%$ sensitive to Gentamicin and Chloramphenicol and $93.3 \%$ to ciprofloxacin but sensitivity recorded for these three antibiotics in present study is lower in percentage i.e. $70.37 \%$ for Gentamicin and Chloramphenicol and $77.77 \%$ for Ciprofloxacin. Verma et al., (2018) reported that Gentamicin $(65.96 \%)$ was the most effective antibiotic, our findings are in partial agreement with this report. Preethirani et al., (2015) reported that Escherichia coli isolates of buffalo mastitis showed $100 \%$ resistance for Amikacin, Amoxycillin/ sulbactam, Ampicillin, Cefotaxime, Ceftriaxone/sulbactam and completely sensitive to Chloramphenicol, which is not in corroboration to our findings. In studies by Ranjan et al., 2011 and Charaya et al., 2014, $E$. coli was found highly sensitive to
Chloramphenicol, Gentamicin, Ciprofloxcin which is similar to findings of present study.

AST is widely used clinical investigation with the sole purpose to select most appropriate antimicrobial agent for therapeutic use. However, it is difficult to judge the clinical efficiency of an antimicrobial agent solely on the basis of AST, as there are large variations in response among herds and within herds, due to type of organism involved, location of infected sites, degree of udder induration, physiochemical properties and kinetic behavior of antibiotics in udder and milk, site of injection and sensitivity of udder pathogens, liquid solubility and tissue protein binding of the drug, $\mathrm{pH}$ of milk and inflammatory exudates/barrier at the site (Srivastava, 2000).

\section{Acknowledgements}

The authors are thankful to the Dean, Veterinary College Mhow for permission and facilities provided to conduct this research work.

\section{Conflict of Interest}

All authors declare no conflict of interest.

\section{References}

Abo-Shama, U.H. (2014). Prevalence and antimicrobial susceptibility of $S$. aureus isolated from cattle, buffalo, sheep and goats's raw milk in Sohag governorate, Egypt. Assiut Veterinary Medical Journal, 60: 141.

Ali, M.A., Ahmad, M.D., Muhammad, K. and Anjum, A. A. (2011). Prevalence of Subclinical mastitis in dairy buffaloes of Punjab. Pakistan Journal of Animal and Plant Science, 21(3) 477-480.

Barrow, G.I. and Feltham, R.K.A. (1993). Cowan and Steel's Manual for the 
Identification of Medical Bacteria. $3^{\text {rd }}$ edn. Cambridge University Press, Cambridge. pp 140-143.

Bauer, A.W., W.M.M. Kirby, J.S. Sherris and M. Turck (1966). Antibiotic susceptibility testing by a standard single disc method. Am. J. Clin. Pathol., 45: 493-496.

Bhanot, V., Chaudhri, S.S. Bisla, R.S. and Singh, H. (2012). Retrospective study on prevalence and antibiogram of mastitis in cows and buffaloes of eastern Haryana. Indian Journal of Animal Research, 46(2):160- 163.

Charaya, G., Sharma, A., Kumar, A., Singh, M., and Goel, P. (2014). Pathogens isolated from clinical mastitis in Murrah buffaloes and their antibiogram. Veterinary World, 7(11): 980-985.

Collee, J.G., Fraser, A.G., Marion, B.P. and Simmons, A. (1996). Mackie and McCartney's Practical Medical Microbiology, $4^{\text {th }}$ edn. Churchill Livingstone, New York.

Cruickshank, R., J.P. Duguid, B.P. Marmion and R.H.A. Swain (1973). Medical Microbiology. Vol. I, $12^{\text {th }}$ edn. E.L.B.S. and Churchill, Livingstone. pp 406-410.

Daka, D., Silassie, S.G. and Yihdego, D. (2012). Antibiotic-resistance Staphylococcus aureus isolated from cow's milk in the Hawassa area, South Ethiopia. Annals of Clinical Microbiology and Antimicrobials, 11: 26.

Dhakal, I.P., Dhakal, P., Koshihara, T. and Nagahata, H. (2007). Epidemiological and bacteriological survey of buffalo mastitis in Nepal. The Journal of Veterinary Medical Science, 69:12411245.

El-Sayed Lamey, A., Ammar, A.M., Zaki, E.R.A., Khairy, N., Moshref, B.S. and Refai, M.K. (2013). Virulence factors of Escherichia coli isolated from recurrent cases of clinical and subclinical mastitis in buffaloes. International Journal of Microbiological Research, 4 (1): 86-94.

Farooq, A.A., Inayat, S., Akhtar, M.S. and Mushtaq, M. (2008). Prevalence of mastitis and antibiotic sensitivity of bacterial isolates recovered from NiliRavi buffaloes. Journal of Animal and Plant Sciences, 18(2): 1018-1022.

Hameed, S., Arshad, M., Ashraf, M., Shahid, M.A. (2008). Prevalence of common mastitogens and their antibiotic susceptibility in tehsil Burewala, Pakistan. Pakistan Journal of Agriculture Sciences, 45(2): 181-183.

Idriss, SH. E., Foltys, V., Tančin, V., Kirchnerová, K., Tančinová, D., Zaujec, K., Foltys, V., Tančin, V., Kirchnerová, K., Tančinová, D. and Zaujec, K. (2014). Mastitis pathogens and their resistance against antimicrobial agents in dairy cows in Nitra, Slovakia. Slovak J. Anim. Sci., 47(1): 33-38.

Jeykumar, M., Vinodkumar, G., Bashir, B.P. and Krovvidi, S. (2013). Antibiogram of mastitis pathogens in the milk of crossbred cows in Namakkal district, Tamil Nadu. Veterinary World, 6(6):354-356.

Kalmus, V., Realo, A. and Siibak, A. (2011). Motives for Internet use and their relationships with personality traits and socio-demographic factors. Trames, 15(4): 385-403.

Khan, A.Z. and Muhammad, G. (2005). Quarter-Wise comparative prevalence of mastitis in buffaloes and crossbred cows. Pakistan Veterinary Journal, 25(1): 9-12.

Kisku, J.J. and Samad, M.A. (2013). Prevalence of sub-clinical mastitis in lactating buffaloes detected by comparative evaluation of indirect tests and bacteriological methods with antibiotic sensitivity profiles In Bangladesh, Buffalo Bulletin, 32(4): 293-306. 
Malik, B.S. (2003). A Laboratory Manual of Veterinary Microbiology. Part I. $4^{\text {th }}$ edn. CBS Publishers and Distributers, New Delhi. pp 67-80.

Moroni, P., Rossi, C.S., Pisoni, G., Bronzo, V., Castiglioni, B., Boettcher, P.J. (2006). Relationships between somatic cell count and intramammary infection in buffaloes. Journal of Dairy Science, 89: 998-1003.

Preethirani, P. L., Isloor, S., Sundareshan, S., Nuthanalakshmi, V., Deepthikiran, K., Sinha, A. Y., Rathnamma, D., Prabhu, K. N., Sharada, R., Mukkur, T.K. (2015). Isolation, biochemical and molecular Identification, and In vitro antimicrobial resistance patterns of bacteria isolated from bubaline subclinical mastitis in South India, Public Library of Science, 39(5)18451849.

Ranjan, R., Gupta, M.K. and Singh, K.K. (2011). Study of bovine mastitis in different climatic conditions in Jharkhand, India. Veterinary World, 4(5): 205-208.

Schalm, O.W., Carroll, E.J. and Jain, N.C. (1971). Bovine Mastitis, $1^{\text {st }}$ edn. Lea Febiger, Philadelphia.

Srivastava, A.K. (2000). Recent concepts on the use of antimicrobials in the treatment of mastitis. Veterinary Microbiology, 3:62-83.

Sumathi, B.R., Veeregowda, B.M. and Gomes, A.R. (2008). Prevalence and antibiogram profile of bacterial isolates from clinical bovine mastitis. Veterinary World, 1:237-238.

Verma, H., Rawat, S., Sharma, N., Jaiswal, V. and Singh, R. (2018). Prevalence, bacterial etiology and antibiotic susceptibility pattern of bovine mastitis in Meerut. Journal of Entomology and Zoology Studies, 6(1): 706-709.

Williams, R. (2000). The impact of antimicrobial resistance. Acta Vet. Scand., Suppl., 93: 17-20.

Zadoks, R. N., Middleton, J. R., McDougall, S., Katholm, J., Schukken, Y. H. (2011). Molecular epidemiology of mastitis pathogens of dairy cattle and comparative relevance to humans. $J$. Mammary Gland Biol. Neoplasia, 16 (4): 357-72.

Zdolec, N., Dobranic, V., Butkovic, I., Koturic, A., Filipovic, I. and Medvid, V. (2016). Antimicrobial susceptibility of milk bacteria from healthy and drugtreated cow udder. Veterinarski Arhiv, 86 (2): 163-172.

\section{How to cite this article:}

Singh, A., D. Chhabra, R. Sikrodia, S. Shukla, R. Sharda and Audarya, S. 2018. Isolation of E. coli from Bovine Mastitis and Their Antibiotic Sensitivity Pattern. Int.J.Curr.Microbiol.App.Sci. 7(10): 11-18. doi: https://doi.org/10.20546/ijcmas.2018.710.002 